\title{
AC 2008-83: DEVELOPMENT OF AN INTERDISCIPLINARY LABORATORY CURRICULUM FOR EMERGING PRODUCT MANUFACTURING
}

\section{Frank Liou, Missouri University of Science \& Technology}

Frank Liou is a Professor in the Mechanical Engineering Department at the Missouri University of Science and Technology (MST). He currently serves as the Director of the Interdisciplinary Manufacturing Engineering Program at MST. His teaching and research interests include $\mathrm{CAD} / \mathrm{CAM}$, rapid prototyping, and rapid manufacturing. He has published over 150 technical papers, and has research grants and contracts over $\$ 8 \mathrm{M}$. 


\title{
DEVELOPMENT OF AN INTERDISCIPLINERY LABORATORY CURRICULUM FOR EMERGING PRODUCT MANUFACTURING
}

\begin{abstract}
$\underline{\text { Abstract }}$
This paper summarizes an effort to develop an interdisciplinary capstone design project course and laboratory in manufacturing. As manufacturing laboratories are very expensive to develop, this program is designed based on distributed and integrated manufacturing processes on campus. As students can gain access to various facilities, they will be able to make various products, including some emerging products, such as EDM machines, fuel cells, etc. As this capstone design project provides opportunities for students to design, manufacture, it stimulates the students' interest in real-world product realization. Both the program model and actual project implementation are summarized in this paper. This program can also be adapted at other institutions that have limited manufacturing process facilities.
\end{abstract}

\section{Introduction}

Establishment of laboratories for a manufacturing program is typically challenging as it tends to be costly in terms of capital investment, maintenance, personnel training, and laboratory space. An innovative product-oriented manufacturing curriculum has been implemented ${ }^{1,2}$. This project has significantly impacted two BS degree option programs in manufacturing and the MS degree programs in manufacturing. We have established an integrative and collaborative manufacturing program to reinforce and sharpen critical competencies of students. The centerpiece and uniqueness of this program is a seniorlevel, two-semester capstone manufacturing project course that provides students with the experience of integrating business and engineering skills toward distributed product realization. The term "distributed" is used to emphasize that the student team is expected to use facilities that are distributed at manufacturing laboratories on both campuses and the facilities of outside vendors and suppliers. This project course also provides students with the experience of integrating the technical knowledge they have learned from other courses. The objectives of this program and learning outcomes include 1) Ability for students to design and conduct experiments, as well as to analyze and interpret data;2) Ability for students to design a system, component, or process to meet desired needs; 3 ) Ability to function on multi-disciplinary teams; 4) Ability for students to identify, formulate, and solve engineering problems; 5) Ability for students to use the techniques, skills, and modern engineering tools necessary for engineering practice; and 6) Ability to attract industry to participate. The current development effort for emerging products for the courses and the current assessments are reported in this paper.

\section{Capstone Project Courses}

The two-semester capstone project courses have been developed and offered. The twocourse sequence enables the students to learn in the following subjects:

1. Acquisition of customer's requirements, 
2. Problem formulation,

3. Cost estimation,

4. Product conceptual design,

5. Product representation (Solid Modeling),

6. Product conceptual prototyping,

7. Make/buy decision,

8. Manufacturing process capabilities,

9. Manufacturing process identification,

10. Process planning,

11. Fabrication and Assembly.

In this course, interdisciplinary teams with students from various engineering and technology disciplines worked together to design, manufacture, and assemble real-life products. Senior students in manufacturing options participated in this course. Students in the MS program actively participated in the project as part of their practice-oriented credit requirement. The project courses take advantage of the manufacturing options being offered in both the Mechanical Engineering and Engineering Management departments. It is intended to simulate the modern industrial product development and manufacturing process in which engineers from various disciplines work together, and each team member contributes his/her expertise to accomplish the project. We invited students from various disciplines to enroll in this course. Typically there are 20 students enrolled in the class, from Engineering Management, Manufacturing Engineering, and Mechanical Engineering majors. Students in Mechanical Engineering have a solid background in product configuration/definition/ analysis, process development, and some manufacturing processes, while students in Engineering Management have a good knowledge in marketing/cost analysis, quality engineering, and project management, and students in Manufacturing Engineering are more familiar with manufacturing processes, and hands-on fabrication experience. They actually worked in teams with expertise to perform concurrent product design and manufacturing.

Their customer is the sponsoring company or a faculty research project for prototyping a product, or in testing a new process. In case the produced product is a prototype, the students have to develop marketing and manufacturing plans for quantity production. Student teams made presentations each week to report their project progress. In this way they can learn from each other at various product development stages. We found that this also provided great motivation for each team to keep good pace with the other teams.

\section{Distributed Manufacturing Laboratory}

Since manufacturing facilities are very capital intensive and require constant maintenance, it is a major challenge to maintain all the facilities for student use. Many of the experiences of the product realization process concurrently gained by students are severely limited by the types of manufacturing processes available at their universities. Also, it is unrealistic to expect that every institution will be equipped to handle a broad range of "real-life" products used for product realization projects. This curriculum development effort also integrated the existing campus manufacturing resources and 
those available from industries to provide distributed manufacturing experiences for students to solve real problems, including some emerging product development. One unique feature of the capstone project is the distributed product realization that ties together product realization process and supply chain management.

We have experimented with a distributed product realization model that can be replicable at other institutions. The word "distributed" means that the manufacturing capability that is available at the disposal of the student team is distributed at 1) the home institution, 2) catalog part suppliers and vendors available through the internet and/or catalogs, and 3) job-shop vendors and suppliers who accept designs from clients before quoting. This concept has been implanted through two mechanisms: 1) A web site has been developed to document the campus manufacturing resources. The information includes machine types, machine configurations and capabilities, etc. so that students are able to make a decision in process selection for their product, and 2) The Manufacturing Engineering program provides the necessary coordination and sometimes provides resources to ensure that the students will have access to the desired facilities.

Students have access to the internet, handbooks, and catalogs to procure parts. Furthermore, students also have access to a selected list of vendors/suppliers (with varied degrees of manufacturing process capability) who would supply quotes based on the design drawings supplied by the student team. Based on product complexity, the student team is provided with the approximate percentage of parts and part types that can be manufactured in-house, procure "off the shelf" components from catalog vendors, or request bids for some of their component drawings with vendors. Through this scenario, we will be able to provide students with the experience and "know-how" of the tactical advice on developing both effective logistics operations and a unique insight into the operating environment for sourcing and procurement. For example, students can produce a product by making parts in-house, working with a vendor to produce a plastic or composite component, or matching and integrating with an ordered motor through the catalog. The distributed websites allows students much more flexibility and resources in the product development process. The integration, management, and communication involved in the process creates a meaningful experience for all the students and faculty participating in the project.

\section{Modular Courseware for Curriculum Support}

We have adapted, developed, and implemented several modular courseware to support the capstone course and laboratory. Since the project oriented course teams are multidisciplinary, we realize that students from different disciplines will have different technical backgrounds. However, if they have to work effectively in a team, there needs to be some common level of knowledge, especially where the integration of student know-how occurs. We adapted, developed, and used modular courseware to enable the students to effectively communicate with each other and execute the project. The courseware are web-based and some are video-based. We have looked at several projects that are aimed at reforming the undergraduate design and manufacturing engineering curriculum. The course modules from theses resources have been adapted and integrated 
with the developed modules to support the capstone project course. They are selfcontained, with practical examples, and fully accessible to students through the web and video. The modules include: team-based product development, project management, supply chain management, Unigraphics, Pro-E, product marketing and cost analysis, rapid prototyping, measurement and gauging, product assembly, welding, metal forming, punching, etc.

Each capstone project team is required to document their project through a multimedia presentation and report. A library collecting these reports, to be maintained by the manufacturing program, has been established and available for other students to learn about the project's history. Successful or not, each case represents a valuable experience to be shared with others. The end product of the first course is to deliver a concept prototype and the second course is an engineering prototype.

\section{Some Class Examples}

The classes have been offered in the past seven years. We found the students are very interested in working on emerging products that are current and intriguing. Two recent products are briefly summarized here, including an EDM machine and a fuel cell to power a boat.

\section{Wire-EDM Machine}

In this project, a desktop sized wire EDM has been designed and constructed. The objective of this project was to design and construct a desk top sized Wire EDM which can cut simple 2D figure on electrical conductive materials, such as including titanium alloys and tool steels. The prototype cost should be controlled within $\$ 1,000$. The machine includes four systems: wire supply system, X-Y table control system, tank and electrical circuits.

The virtual prototype for Wire-EDM was built using Solid Works as shown in Figure 1. The purposes for building virtual prototype include the followings: 1) Check the design plan. For example, when the prototype was built, it was found that there were some errors in the original design plan, thus the parts could not be assembled properly with the standard components; 2) Make all the parts easy to machine. With the 3D model, it is easy to generate 2D and 3D drawings and communicate with the machine shop, and consequently saves time and energy; and 3) Make the assembly process easy. Completing the assembly in virtual environment makes the operators familiar with the process. 

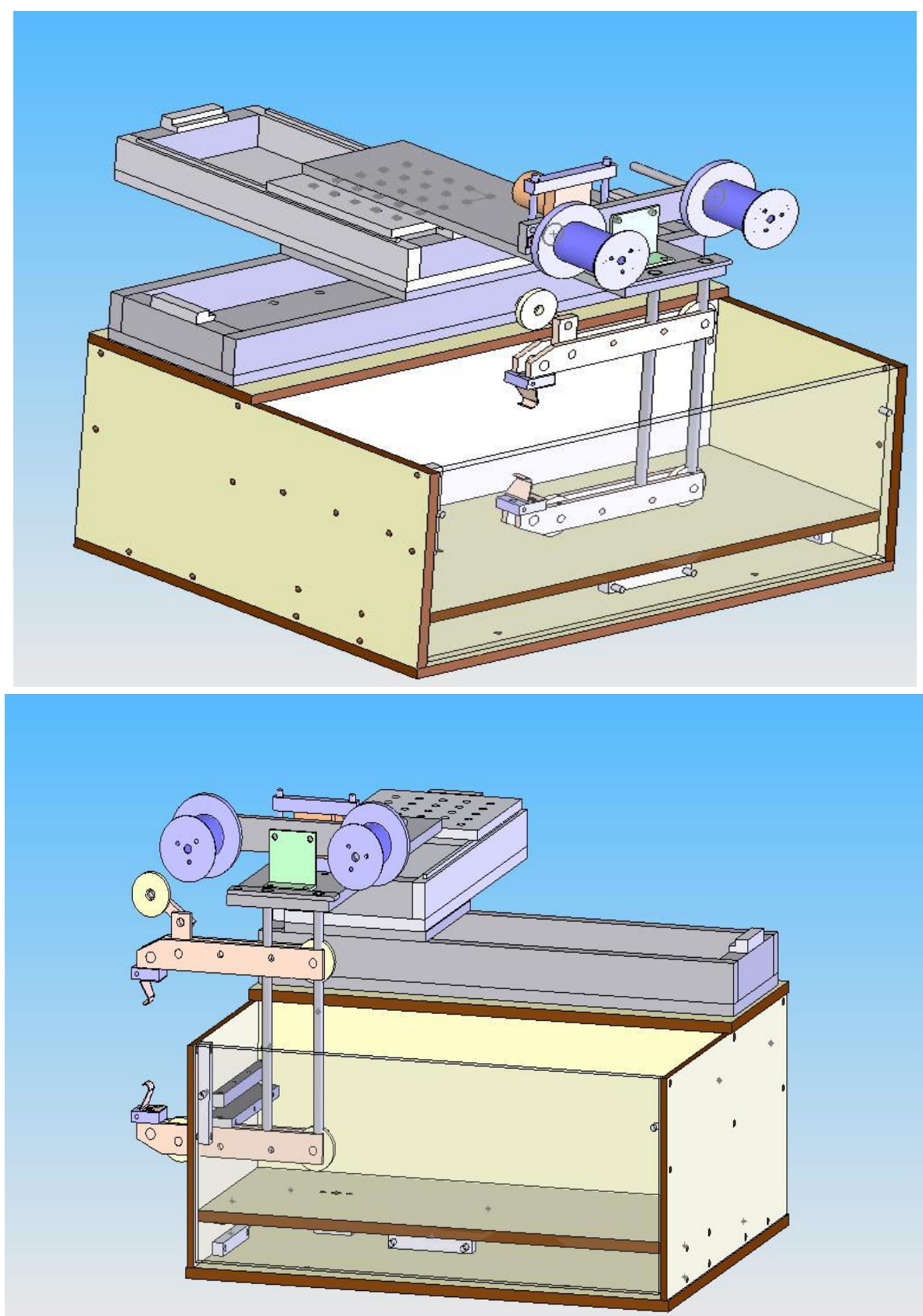

Figure 1. The virtual prototype of the Wire-EDM 

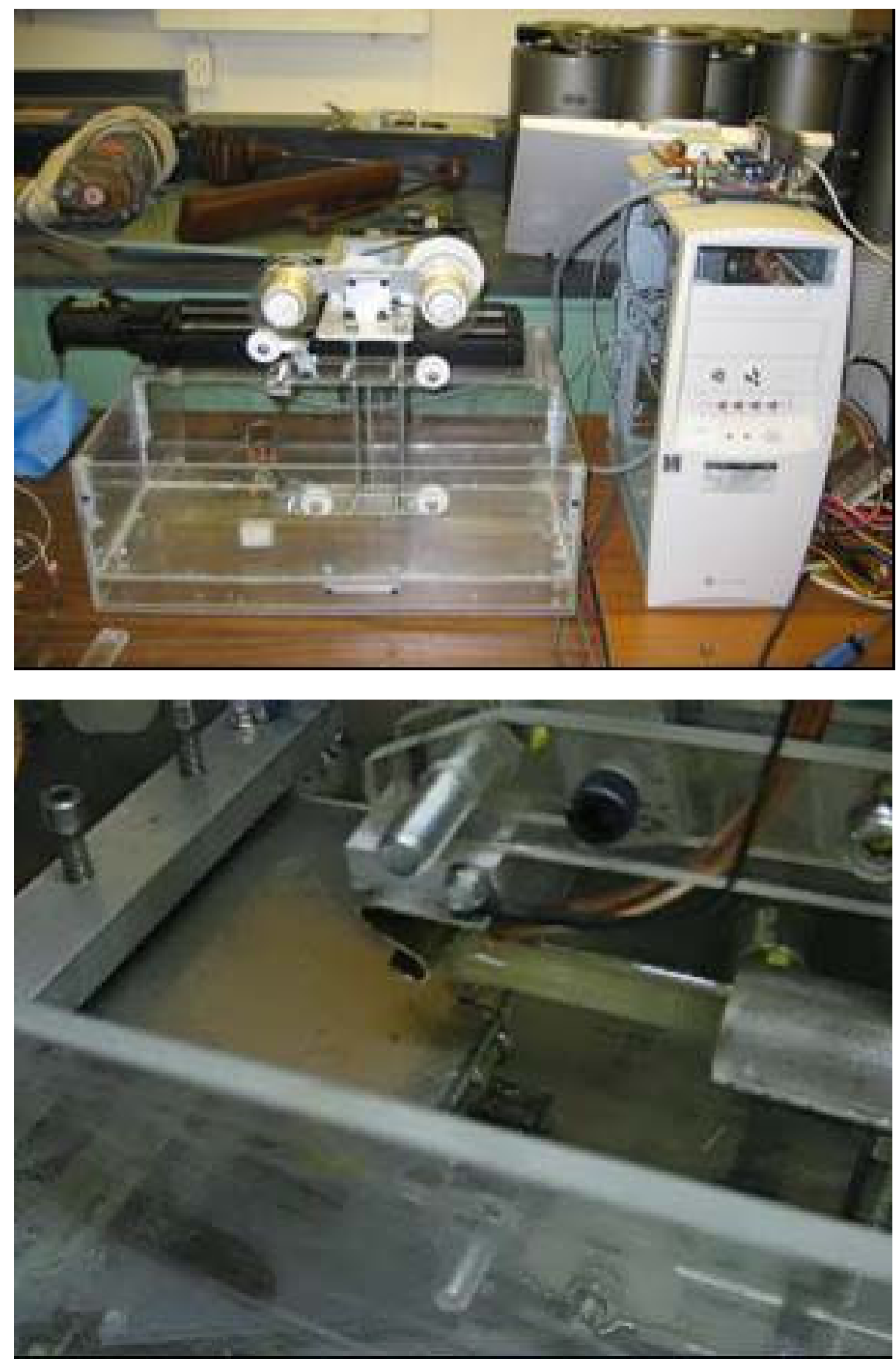

Figure 2. Realization of the wire-EDM machine: system oval (top) and cutting a titanium sample (bottom).

Several manufacturing processes were identified to machine parts for this Wire-EDM: 1) Cutting. Cut the raw material including aluminum, steel and Trespa to proper size to be 
machined; 2) Milling. Mill was used to machine the block parts; 3) Turing and boring. Lathe was used to machine the pulleys, etc.; 4) Drilling and broaching. Drill and broach holes were used to assemble the parts together; and 5) Rapid prototyping: FDM (Fused Deposition Modeling) was used for physical prototyping and for actual fabrication of some parts. Figure 2 shows the complete prototype of the wire-EDM machine, and the total project cost is $\$ 884.02$. It can cut both titanium and tool steel. Although the cutting speed can be improved, this project was a success and the customer is satisfied.

\section{Fuel Cell}

The purpose of this project was to design and assemble a simple fuel-cell using university laboratory and off-the-shelf components. This fuel cell is targeted to power a toy boat. The idea is to make use of the solar energy and water to produce hydrogen to power the fuel cell. The water that the boat was floating in could easily act as a source of hydrogen through electrolysis. This design was refined through various processes and testing. All components were machined, built, or purchased in the simplest form available as shown in Figure 3. Figure 4 shows the solid model of the final design. The major cost of the fuel cell was the membrane. It comprised of almost $80 \%$ of the total cost. All of the costs added up to a total cost of $\$ 204.69$.

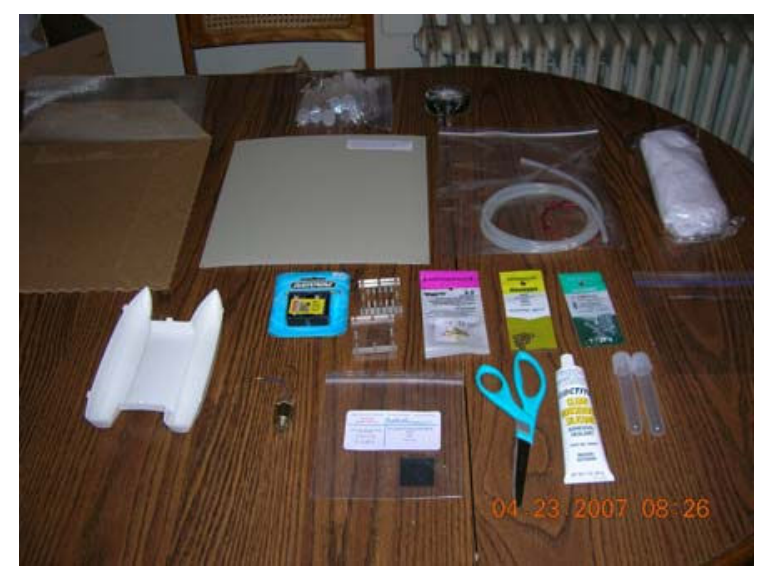

Figure 3. Purchased items: male housing, female housing, copper wire, wire mesh, silicon gasket, proton exchange membrane (PEM), and various small hardware.

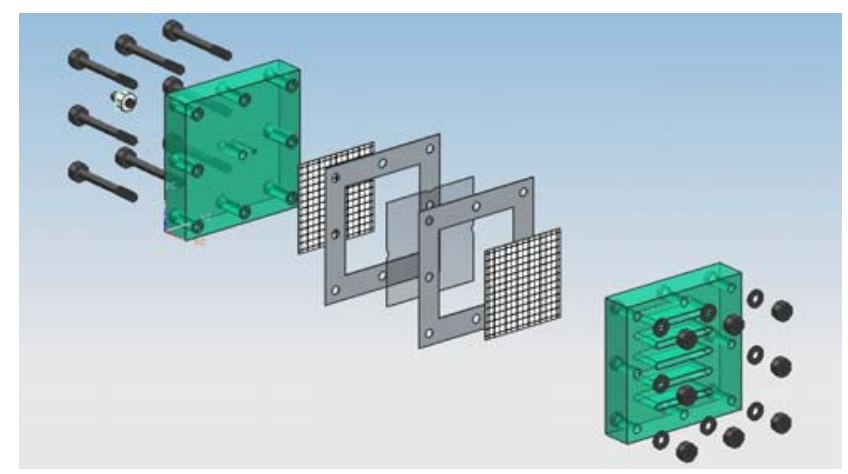

Figure 4. Solid model of the final fuel cell design. 
Figure 5 shows the assembled fuel cell installed in the toy boat, and Figure 6 shows that the fuel cell was used to power the propeller. The test and measurement plan consisted of a series of small tests that determined whether or not the prototype has met its required objectives. Tests were conducted to verify the following objectives originally specified:

1) Power the vehicle for $\geq 60$ seconds: The fuel-cell was pre-charged to approximately $0.8 \mathrm{~V}$ at which run time, and the maximum and minimum run times were $313 \mathrm{~s}$ and $280 \mathrm{~s}$.

2) Weight of fuel-cell assembly $\leq 2$ pounds: A total fuel-cell assembly weight is $0.21 \mathrm{lbs}$

3) Voltage $\geq 0.6$ Volts: For each trial, the fuel-cell was pre-charged to approximately $0.8 \mathrm{~V}$ at which time the motor was turned on. The results show the maximum voltage across the motor for each run and it can be seen that the maximum voltage range across the motor is $0.04 \mathrm{~V}$. The highest and lowest maximum voltages across the motor are $0.67 \mathrm{~V}$ and $0.63 \mathrm{~V}$, respectively.

4) Total prototype weight $\leq 5$ pounds: Weighing the complete prototype assembly resulted in a total prototype weight of $0.45 \mathrm{lbs}$.

5) Steps to assemble/disassemble $\leq 10$ : Counting the assembly steps resulted in a total of 18 steps, and thus this goal was not achieved.

6) By-products limited to water: Yes.

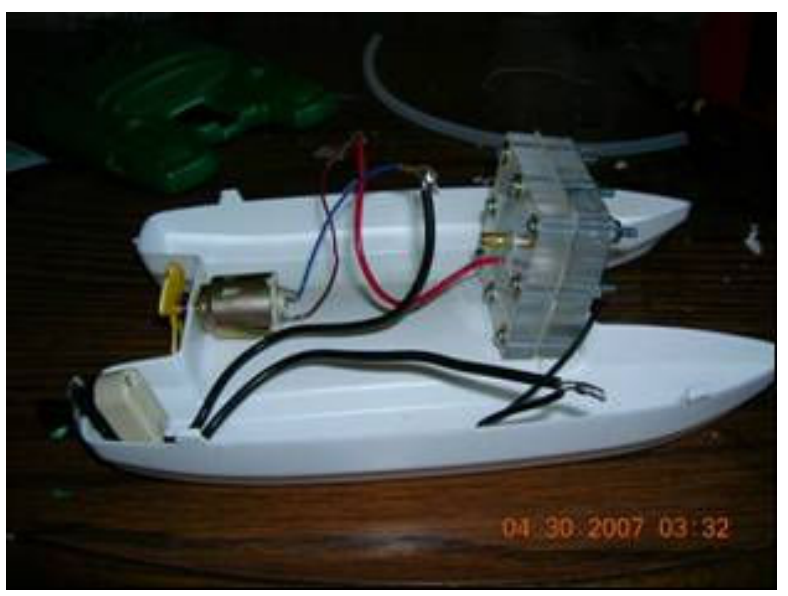

Figure 5. Assembled fuel cell installed in the toy boat.

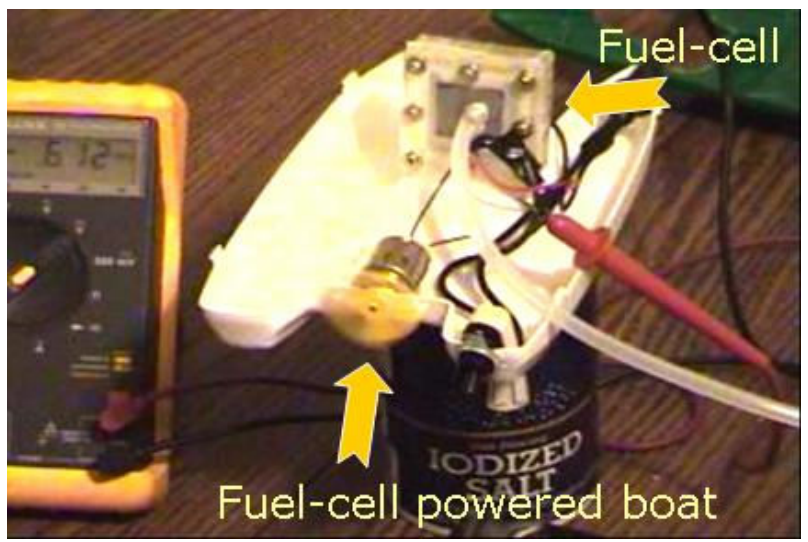

Figure 6 . The fuel cell was used to power the propeller. 
The result was a fuel-cell powered boat that consistently produced a $0.63 \mathrm{~V}$ for over 3 minutes.

\section{Program Outcomes}

The classes have been offered for over 7 years. The following data is summarized based on this year's (2007) exit interview of graduating students to observe the recent feedback. About 20 students were surveyed, and 10 feedbacks were received. The assessment is based on the expected program outcomes. Two sets of questions were asked:

A) How important is it to you? 'Check a number between ' 1 ' and ' 5 ', with ' 1 ' being not important, and ' 5 ' being very important."

B) How effective is this program? "Check a number between ' 1 ' and ' 5 ', with ' 1 ' being not effective, and ' 5 ' being very effective."

1) Ability for students to design and conduct experiments, as well as to analyze and interpret data

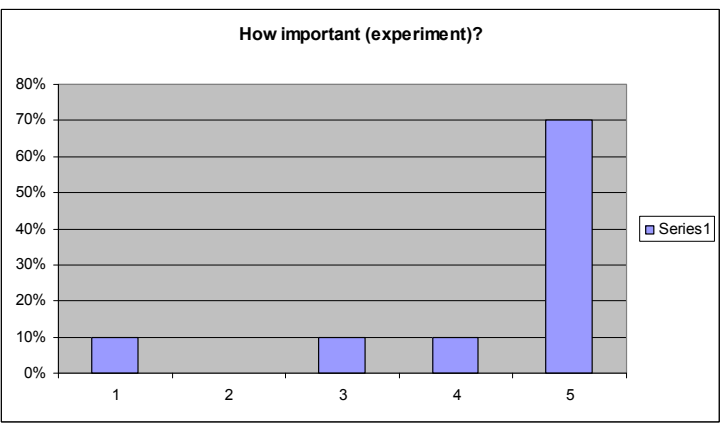

A) How important is it to you

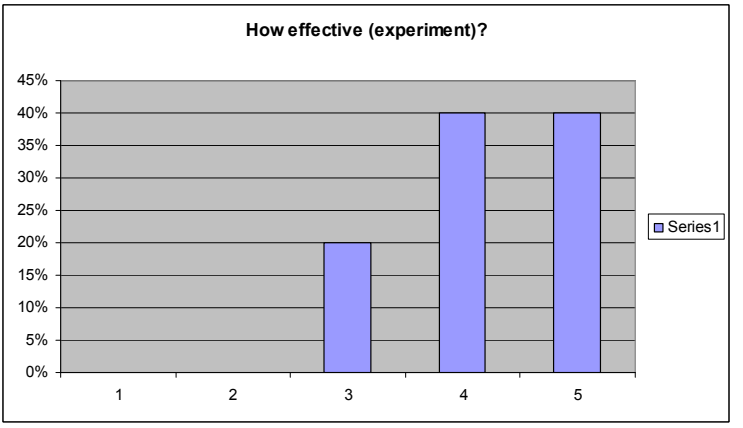

B) How effective is this program

2) “Ability for students to design a system, component, or process to meet desired needs"

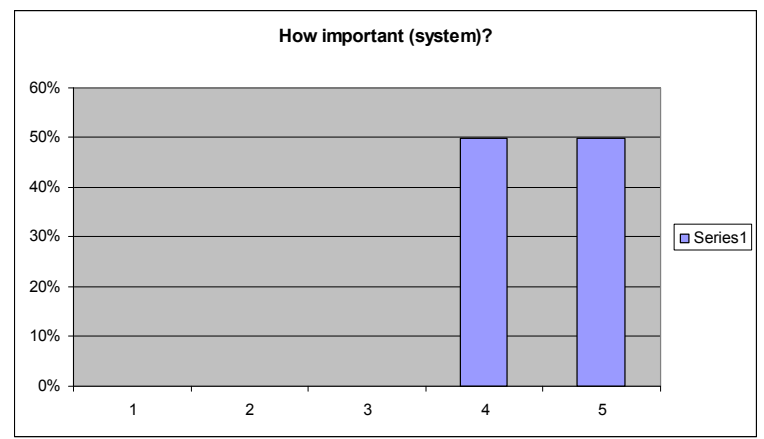

A) How important is it to you

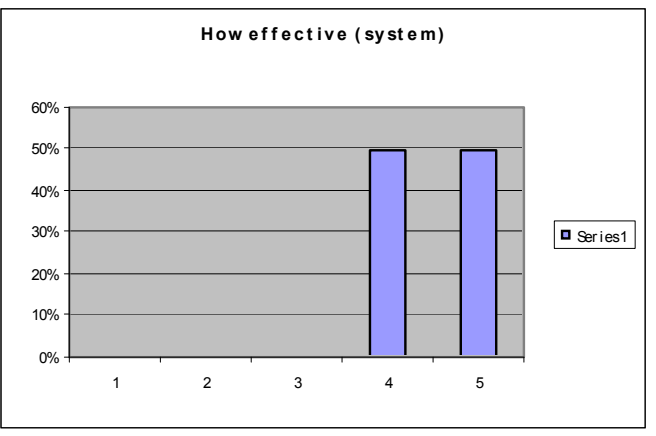

B) How effective is this program 
3) "Ability to function on multi-disciplinary teams"

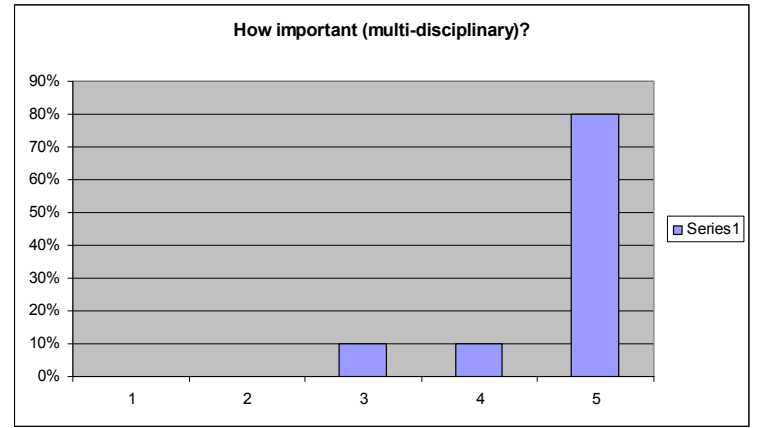

A) How important is it to you

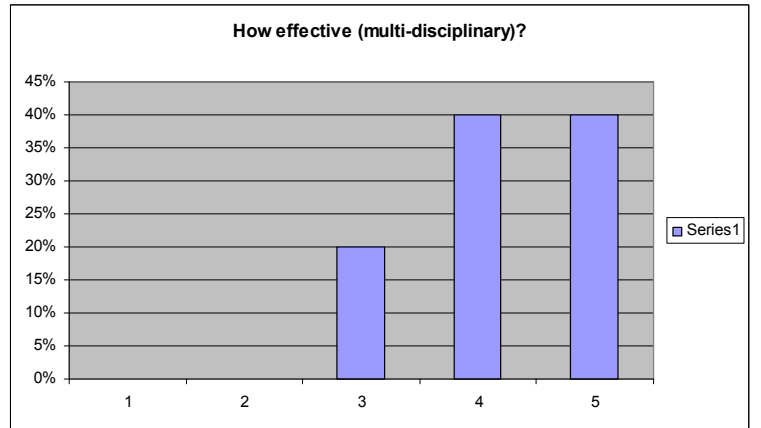

B) How effective is this program

4) "Ability for students to identify, formulate, and solve engineering problems"

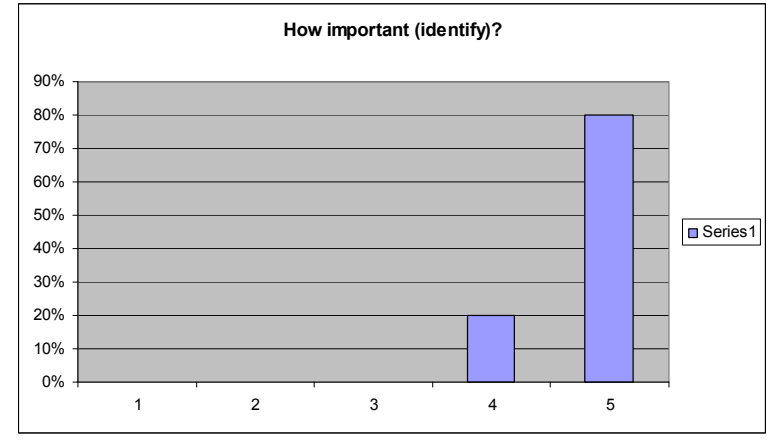

A) How important is it to you

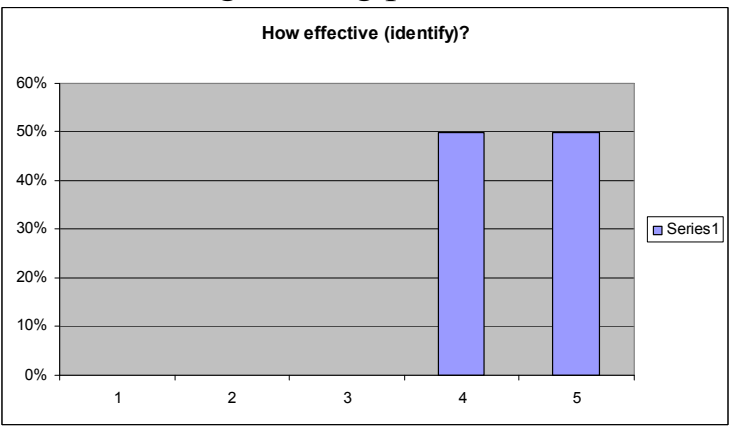

B) How effective is this program

5) "Ability for students to use the techniques, skills, and modern engineering tools necessary for engineering practice"

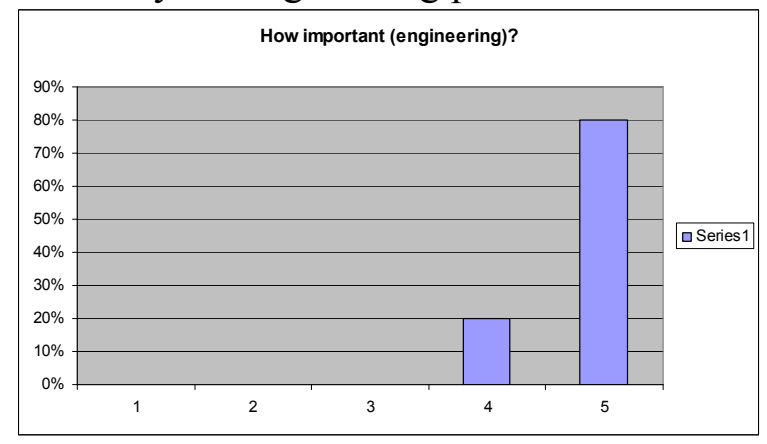

A) How important is it to you

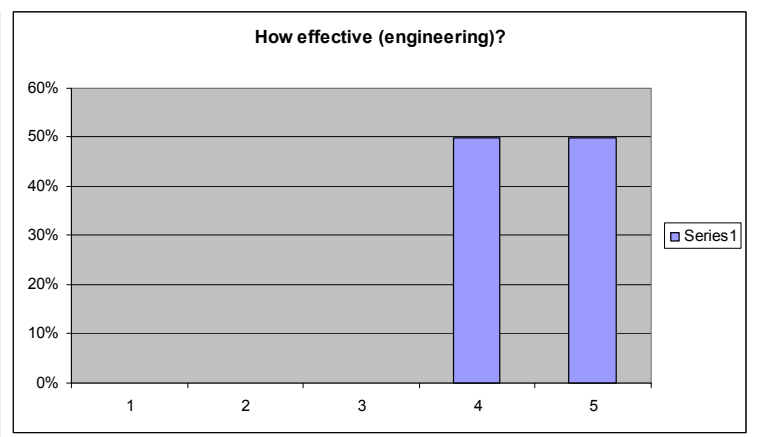

B) How effective is this program

6) Ability to attract industry to participate.

The partnership with industry is a critical step to the success of the project. In the past few years, many companies participated in the project course by sponsoring the capstone projects. They include: 
- WOOD PRO, Cabool, MO

- EYES OF THE WORLD, Rolla, MO

- WATLOW INDUSTRIES, St. Louis, MO

- META STABLE, St. Louis, MO

- DESIGN OPTIMIZATION TECHNOLOGIES, St. Louis, MO

- PRIER PRODUCTS, Grandview, MO

- MISSOURI ENTERPRISE, Rolla, MO

- FORD MOTOR COMPANY, Detroit, MI

- GENERAL MOTORS, Detroit, MI

- THE BOEING COMPANY, St. Louis, MO

- PRODUCT INNOVATION AND ENGINEERING, LLC, Rolla, MO

- SPARTAN LIGHT METAL PRODUCTS, Inc, Sparta, IL

- RPM AND ASSOCIATES, Rapid City, SD

- INTELLIGENT SYSTEMS CENTER, UMR, Rolla, MO

- NATIONAL SCIENCE FOUNDATION

- AIR FORCE RESEARCH LABORATORY, Wright-Patterson, OH

- Several individual inventors

These companies/institutions also invested their engineering time and other resources to the project. Students were given real-life projects based on manufacturing processes and were required to analyze unit steps and suggest possible innovations. Many industries have instituted worker incentive programs that seek suggestions for product and process improvement. We would like to introduce this concept in the classroom to train young minds to 'think differently' and implant the seeds for them to become future process innovators.

\section{Conclusion}

These capstone project courses have been implemented and offered for seven years. The current focus has been on the emerging products as the students found these projects intriguing. The sponsorships are critical as these allow students to purchase the critical components. With the coordination of the Interdisciplinary Manufacturing Engineering program, the students can access almost all the facilities. However, some of the facilities require excessive training before they can operate the machinery. Therefore, careful coordination and planning of team members with the appropriate background are important when forming the team.

The feedback and results were very encouraging. Based on the experience so far, we have found that the major challenges encountered were project timing and facilities. The students greatly benefited from the weekly project presentations given by each group. This not only forced them to keep pace with the other groups in the project schedule, they also learned from each other on how to proceed through each of the steps. According to the students' feedback, the fact that they could simultaneously observe the other projects and how the other groups defined their projects, formulated the problem, designed the product, ordered the off-the-shelf components, fabricated the parts, and put them together, was a great learning process. 
Timing was critical due to the fact that all projects were industrial sponsored, and thus this added pressure to the students as well as the instructor. However, this also created a real industrial environment and its constraints into the classroom. Some factors critical to making the project run more smoothly in terms of timing included the time needed to define the project as well as the time required for material purchasing. Help from the industrial sponsors to provide the necessary and timely support to define project scope at the beginning of the project was critical to the success of the project. The students also needed to be aware of the schedule to order off-the-shelf parts. "Next day service" did not always happen since some products were not in stock, and the students, at times, had to wait several weeks before the part was shipped.

\section{Acknowledgements}

This project is supported by the Society of Manufacturing Engineers Education, Foundation Grant Number 010291, and National Science Foundation Grant Number IIP0637796. The support from many companies and institutions is also appreciated.

\section{Bibliography}

1. Frank Liou, Venkat Allada, Ming Leu, Rajiv Mishra, and Tony Okafor, and, Ashok Agrawal, "A Product Focused Manufacturing Curriculum, 2002 ASEE Annual Conference \& Exposition, Montréal, Quebec, Canada, June 16-19, 2002.

2. Frank Liou, Venkat Allada, Ming Leu, Rajiv Mishra, and Tony Okafor, and, Ashok Agrawal, "An Integrated And Distributed Environment For A Manufacturing Capstone Course," Proceedings of The 2003 ASEE Annual Conference \& Exposition, Nashville, TN, June 22-26, 2003. 